\title{
PENGARUH MODEL PEMBELAJARAN INKUIRI DAN KEMAMPUAN METAKOGNITIF TERHADAP HASIL BELAJAR FISIKA SISWA SMA
}

\author{
Fariza Resti ${ }^{1, \text { a) }}$, I Made Astra, Betty Zelda \\ 1) Program Magister Pendidikan Fisika, FMIPA UNJ \\ Jl. Pemuda No. 10, Jakarta 13220 \\ Email: a) fariza_libra89@yahoo.com
}

\begin{abstract}
Abstrak
Penelitian ini bertujuan mengetahui: (1)Perbedaan hasil belajar fisika bagi siswa yang menggunakan model Inkuiri Mandiri(IM) dan Inkuiri Terbimbing(IT);(2)Pengaruh interaksi antara model pembelajaran Inkuiri dan kemampuan metakognitif terhadap hasil belajar fisika siswa;(3)Perbedaan hasil belajar fisika bagi siswa yang memiliki kemampuan metakognitif tinggi dengan model Inkuiri Mandiri dan Inkuiri Terbimbing;(4)Perbedaan hasil belajar fisika bagi siswa yang memiliki kemampuan metakognitif rendah dengan model Inkuiri Mandiri dan Inkuiri Terbimbing. Populasi target dari penelitian ini adalah siswa/i SMA Negeri 96 Jakarta dan populasi terjangkaunya adalah siswa/i kelas X di SMA Negeri 96 Jakarta. Sampel diambil menggunakan teknik random dari 7 kelas dan didapatkan 4 kelas. Data dikumpulkan dari tes kemampuan metakognitif dan hasil belajar, kemudian di analisis menggunakan ANAVA dua jalur. Hasil penelitian menunjukkan bahwa: (1) Hasil belajar fisika yang menggunakan model IM lebih tinggi dibandingkan IT;(2) Tidak terdapat interaksi antara model pembelajaran inkuiri dan Kemampuan Metakognitif terhadap hasil belajar fisika; (3) Bagi siswa yang memiliki kemampuan metakognitif tinggi, hasil belajar fisika dengan model IM lebih tinggi daripada IT;(4) Bagi siswa yang memiliki kemampuan metakognitif rendah, hasil belajar fisika dengan model IM lebih rendah daripada IT
\end{abstract}

Kata-kata kunci: Inkuiri, Kemampuan Metakognitif, Hasil Belajar Fisika, Kelas X.

\begin{abstract}
This study aims to determine: (1) Differences in the results of physics learning for students using Inkuiri Mandiri (IM) and Inkuiri Terbimbing (IT) model; (2) Influence of interaction between Inquiry learning model and metacognitive ability to student physics learning result; (3) Differences in the results of physics learning for students who have high metacognitive skills with Inkuiri Mandiri and Inkuiri model are guided, (4) Differences in physics learning outcomes for students who have low metacognitive ability with Inkuiri Mandiri model and Guided Inquiry. Target population of This research is a student of SMA Negeri 96 Jakarta and its inaccessible population is student of $\mathrm{X}$ class at SMA Negeri 96 Jakarta. The sample was taken using random technique from 7 classes and got 4 classes. Data collected from the test Metacognitive ability and learning outcomes, then analyzed using two-way ANAVA. The results showed that: the results showed that: (1) The result of physics learning using IM model is higher than IT; (2) There is no interaction between models Inquiry learning and metacognitive ability on physics learning outcomes;

(3) For students who have high metacognitive ability, physics learning outcomes with IM model is higher than IT;

(4) For students who have low metacognitive ability, the learning outcomes of physics with IM model is lower than IT.
\end{abstract}

Keywords: Inquiry, Metacognitive Ability, Physics Learning Outcomes, Class X. 


\section{PENDAHULUAN}

Kurikulum 2013 diimplementasikan secara bertahap di SMA mulai tahun pelajaran 2013-2014 menekankan pendekatan pembelajaran saintifik. Model pembelajaran yang diperlukan adalah yang memungkinkan terbudayakannya kecakapan berpikir sains dan kemampuan berpikir kreatif peserta didik. Sejalan dengan perkembangan paradigma pendidikan abad ke-21, pendidikan di Indonesia dihadapkan pada tantangan untuk menghasilkan sumber daya manusia yang memiliki kompetensi unggul yang mampu bersaing secara global di masa mendatang. Kompetensi yang diharapkan dapat dimiliki sumber daya manusia lebih menitikberatkan pada kompetensi berpikir dan komunikasi. Kompetensi berpikir artinya bahwa diharapkan sumber daya manusia memiliki pengetahuan yang luas, kemampuan berpikir kritis, dan kemampuan berpikir kreatif. Yunus[1] menyatakan kompetensi komunikasi artinya bahwa sumber daya manusia hendaknya memiliki kemampuan berkomunikasi dalam rangka bekerja sama dan menyampaikan ide-ide kritis kreatifnya. Kompetensi ini sangat dibutuhkan dalam proses pembelajaran, salah satunya pada mata pelajaran fisika. Fisika adalah salah satu mata pelajaran dalam rumpun sains yang dapat mengembangkan kemampuan berpikir analitis, induktif, dan deduktif dalam menyelesaikan masalah yang berkaitan dengan peristiwa alam sekitar, baik secara kualitatif maupun kuatitatif dengan menggunakan matematika, serta dapat mengembangkan pengetahuan, keterampilan, dan sikap percaya diri. Berkaitan dengan hal tersebut, kompetensi berpikir dan komunikasi sangat dibutuhkan dalam pembelajaran fisika untuk mencapai keberhasilan dari proses pembelajaran.

Namun pada kenyataannya, pembelajaran fisika saat ini belum berhasil membentuk kemampuan ber pikir kritis dan kreatif siswa serta kemampuan berkomunikasi yang baik pada siswa. Hal ini dapat terlihat dari hasil Programme for International Student Assessment (PISA) pada tahun 2012 yang bertema "Evaluating School Systems to Improve Education" diikuti oleh 65 negara, Indonesia menduduki urutan 64 atau urutan kedua terbawah setelah Peru setelah Peru dengan rata-rata skor science 382[2]. SMA Negeri 96 Jakarta merupakan sekolah sasaran pelaksanaan Kurikulum 2013 mulai tahun 2013-2014. Hasil yang kurang memuaskan juga terlihat dari hasil belajar fisika yang dicapai siswa SMA Negeri 96 Jakarta pada Ujian Akhir Semester (UAS) tahun ajaran 2016/2017. Siswa/I kelas X di SMA Negeri 96 Jakarta memiliki nilai rata-rata sebesar 62,82. Peserta didik dalam mengikuti materi pelajaran belum menunjukkan hasil yang diharapkan. Salah satu model pembelajaran yang disarankan pada kurikulum 2013 adalah model inkuiri, model ini sangat baik digunakan dalam proses pembelajaran. Model inkuiri merupakan suatu kegiatan belajar yang melibatkan secara menyeluruh kemampuan siswa untuk mencari dan menyelidiki secara sistematis, kritis, logis, analitis, sehingga mereka dapat merumuskan sendiri penemuannya. Sasaran utama pembelajaran inkuiri adalah (1) keterlibatan siswa secara maksimal dalam proses pembelajaran, (2) keterarahan kegiatan secara logis dan sistematis pada tujuan pembelajaran, (3) meningkatkan rasa ingin tahu dan mengembangkan sikap imiah dan percaya diri tentang masalah yang ditemukan dalam proses pembelajaran.

Untuk mengatasi permasalahan yang ada maka salah satu upaya yang dilakukan adalah dengan mencari suatu variasi model pembelajaran atau strategi pembelajaran, diantaranya adalah model pembelajaran yang dapat dibangun kemampuan metakognitisnya dalam memahami suatu konsep fisika, dimana selama proses tersebut kesadaran kognisi siswa dapat ditumbuhkan dan memberikan arahan pada siswa untuk bertanya pada diri sendiri apakah mampu memahami apa yang sedang dipelajari. Garrett dan Mazzocco[3] menyatakan bahwa siswa juga diarahkan untuk dapat menyadari apa yang diketahui dan apa yang tidak diketahui serta bagaimana pemecahan masalah, membuat tahap-tahap pemecahannya, memberi lasan mengapa melakukan hal demikian, memonitir proses pemecahan masalah dan kemajuan ke arah tujuan saat melaksanakan rencana dan mengevaluasi apa yang sudah dilakukan.Dengan menggunakan model pembelajaran yang tepat dan sesuai dalam proses pembelajaran dan ditambah dengan memperhatikan kemampuan metakognitif siswa, diharapkan akan mampu meningkatkan hasil belajar siswa semakin baik.

Metakognitif adalah suatu pengetahuan yang berisi pengetahuan metakognisi dan pengalaman metakognitif, yaitu suatu pengetahuan yang dapat digunakan oleh seseorang untuk mengontrol proses kognitifnya. Dengan demikian metakognitif merupakan aktivitas abstrak, yang terkadang secara kasat mata tidak disadari telah dimiliki seseorang dikarenakan merupakan proses mental.Pengalaman 
metakognitif adalah suatu langkah dan tahapan keterampilan atau hasil olah pikirnya selama dalam proses menyelesaikan masalah-masalah yang dihadapinya. Bila dikaitkan dengan proses belajar, maka kemampuan metakognitif adalah suatu kemapuan yang dimiliki seseorang dalam mengendalikan proses belajarnya, yang dimulai dari tahap perencanaan, memilih strategi yang tepat dalam memecahkan masalah, memonitor kemajuan dalam belajar dan pada akhirnya secara bersamaan mengoreksi bila ada kesalahan yang terjadi selama memahami konsep, menganalisis keefektifan dari strategi yang dipilih.

Dengan menggunakan model pembelajaran yang tepat dan sesuai dalam proses pembelajaran dan ditambah dengan memperhatikan kemampuan metakognitif siswa diharapkan akan mampu meningkatkan hasil belajar siswa semakin baik. Berdasarkan latar belakang di atas, maka penulis tertarik untuk melakukan penelitian yang berjudul "Pengaruh Model Pembelajaran Inkuiri dan Kemampuan Metakognitif Terhadap Hasil Belajar Fisika Siswa SMA"

\section{METODE PENELITIAN}

Penelitian ini dilaksanakan di SMA Negeri 96 Jakarta pada kelas X semester genap tahun ajaran 2016/2017. Waktu penelitian dilakukan pada bulan April 2017. Populasi target dari penelitian ini adalah siswa/i SMA Negeri 96 Jakarta dan populasi terjangkaunya adalah siswa/i kelas X di SMA Negeri 96 Jakarta. Sampel diambil secara random dari 7 kelas. Berdasarkan hasil pengambilan sampel, didapatkan 4 kelas, dimana 2 kelas ditetapkan menjadi kelas eksperimen dan 2 kelas lainnya menjadikelas kontrol. Metode yang digunakan dalam penelitian ini adalah quasi eksperimen dengan desain Treatment by Level 2x2. Penelitian ini diberikan perlakuan sebanyak 8 (delapan) kali pertemuan. Perlakuan yang diberikan kepada kedua kelompok adalah perlakuan yang berbeda, dimana kelompok pertama yaitu kelas X.1 dan X.2 menggunakan model pembelajaran Inkuiri Mandiri dan kelompok kedua yaitu kelas X.4 dan X.5 menggunakan model pembelajaran Inkuiri Terbimbing. Kedua kelompok tersebut diberikan tes kemampuan metakognitif pada awal perlakuan. Kemudian seluruh kelompok diberikan Posttest untuk mengukur hasil belajar fisika dan menguji perbedaannya pada setiap kelompok.

Instrumen dalam pengumpulan data kemampuan metakognitif adalah angket yang menggunakan skala likert dalam pengukurannya dengan skala 1 sampai 4. Instrumen kemampuan metakognitif disusun sendiri oleh penulis dengan indikator instrumen mengacu kepada teori para ahli yang telah dijabarkan pada kajian theoretik, yaitu mengacu kepada indeks kemampuan metakognitif yang dipaparkan oleh Margaret E,Gedler [4]. Jumlah instrumen soal untuk mengukur kemampuan metakognitif siswa adalah 45 pernyataan. Sebelum soal ini diujikan pada kelas yang dijadikan objek penelitian, soal ini diujikan terlebih dahulu ini pada sekolah SMA Negeri 84 Jakarta untuk melihat apakah soal tersebut valid dan reliabel untuk dijadikan instrumen hasil belajar siswa. Untuk mengetahui validitas instrumen ini yang berbentuk tes uraian digunakan persamaan korelasi product moment dan didapatkan 35 pernyataan valid. Untuk mengetahui realibilitas instrumen ini menggunakan rumus alpha cronbach dan dari hasil perhitungan, instrumen ini bersifat realibel dengan derajat relialibilitas kuat karena memiliki nilai r11 sebesar 0.994028378. Selain instrumen kemampuan metakognitif, data dalam penelitian ini juga diperoleh dari hasil belajar fisika pokok momentum,impuls dan tumbukan. Instrumen yang digunakan dalam pengumpulan data penelitian ini adalah soal tes hasil belajar siswa pada ranah kognitif dalam bentuk pilihan ganda yang disusun sendiri oleh penulis dengan indikator tes ini mengacu pada teori taksonomi Anderson dan Karthwohl [5]. Aspek yang diukur dari kemampuan C1 sampai C6 menurut taksonomi Anderson dan Karthwohl. Jumlah instrumen soal untuk mengukur hasil belajar siswa dalam pembelajaran fisika adalah 40 soal. Kemudian dilakukan validasi untuk instrumen berbentuk tes pilihan ganda digunakan persamaan korelasi point biserial dan didapatkan 30 soal valid. Untuk mengetahui realibilitas instrumen ini menggunakan rumus KR-20 dan dari hasil perhitungan, instrument ini bersifat realibel dengan derajat relialibilitas kuat karena memiliki nilai r11 sebesar 0,91640987. Setelah data terkumpul dilakukan perhitungan statistik untuk membuktikan ada atau tidaknya pengaruh model pembelajaran Inkuiri dan Kemampuan Metakognitif terhadap hasil belajar fisika SMA. 


\section{HASIL DAN PEMBAHASAN}

Sebelum pengujian hipotesis, terlebih dahulu dilakukan uji persyaratan analisis data. Pengujian persyaratan analisis data meliputi pengujian normalitas dan homogenitas variansi populasi. Uji normalitas data dilakukan menggunakan uji Liliefors yang digunakan pada masing-masing kelompok perlakuan dengan menggunakan taraf signifikan $\alpha=0,05$. Dari hasil perhitungan terlihat bahwa nilai Lhitung untuk semua kelompok lebih kecil daripada nilai Ltabel. Dengan demikian dapat disimpulkan bahwa data hasil belajar fisika dari semua kelompok data berasal dari populasi yang berdistribusi normal. Uji homogenitas menggunakan uji Bartlett. Hasil perhitungan dan uji signifikansi varians masing masing kelompok data menunjukkan nilai perhitungan dan uji signifikansi varians masing masing kelompok data menunjukkan nilai $X^{2}$ hitung dari seluruh kelompok data lebih kecil daripada $X^{2}$ tabel pada taraf signifikan $\alpha=0,05$. Dengan demikian dapat disimpulkan bahwa seluruh kelompok memiliki varians yang homogen. Pengajuan hipotesis dalam penelitian ini dilakukan dengan menggunakan ANAVA dua jalur. Kemudian dilanjutkan dengan uji tuckey untuk mengetahui efek utama mana yang lebih tinggi. Perhitungan analisis data hasil belajar fisika dan berdasarkan hasil analisis tersebut dapat dilihat pada tabel dibawah ini:

Tabel 1. Data Statistik Hasil Belajar Fisika Siswa

\begin{tabular}{|c|c|c|c|c|c|}
\hline Sumber Varians & Db & $\mathbf{J K}$ & RJK & Fh & $\begin{array}{c}\mathrm{Ft} \\
(\alpha=0.05)\end{array}$ \\
\hline $\begin{array}{l}\text { Model Pembelajaran Inkuiri } \\
\text { (A) }\end{array}$ & 1 & 1007.042401 & 1007.042401 & 12.85204278 & 3.95 \\
\hline Motivasi Belajar (B) & 1 & 8633.107896 & 8633.107896 & 110.1771602 & 3.95 \\
\hline Interaksi (AXB) & 1 & 106.6026329 & 106.6026329 & 1.360480548 & 3.95 \\
\hline Antar Kelompok & 3 & 9746.75293 & 3248.917643 & 41.46322784 & 2.71 \\
\hline Kekeliruan (dalam sel) & 72 & 5641.675347 & 78.35660205 & - & - \\
\hline Total (T) & 76 & 368900.4005 & - & - & - \\
\hline
\end{tabular}

Berdasarkan hasil perhitungan pada tabel diatas, maka hasil uji hipotesis sebagai berikut:

1. Dari hasil perhitungan ANAVA yang telah dilakukan diatas, didapatkan $F_{\text {hitung }}=12,8>F_{\text {tabel }}=3,95$. Sehingga dapat disimpulkan terdapat perbedaan hasil belajar fisika yang signifikan antara yang menggunakan model IM dengan model IT dimana hasil belajar fisika siswa yang menggunakan model IM lebih tinggi daripada yang menggunakan model IT.

2. Dari hasil perhitungan ANAVA yang telah dilakukan diatas, didapatkan $\mathrm{F}_{\mathrm{h}(\mathrm{I})}<\mathrm{F}_{\mathrm{t}(\mathrm{I})}=\mathrm{F}_{\mathrm{h}}(1.36)<$ $\mathrm{F}_{\mathrm{t}}(3,95)$. Sehingga dapat disimpulkan bahwa tidak terdapat pengaruh interaksi antara model pembelajaran inkuari dan kemampuan metakognitif terhadap hasil belajar fisika siswa.

3. Dari hasil perhitungan ANAVA yang telah dilakukan diatas, terdapat perbedaan yang signifikan pada pengujian hipotesis interaction effect, Didapatkan $f_{\text {tabel }}=3,74$. Karena $f_{\text {hitung }}=41,46>$ $\mathrm{f}_{\text {tabel }}=2,71$ Sehingga dapat disimpulkan terdapat perbedaan hasil belajar fisika yang signifikan antara yang menggunakan model IM dengan model IT khusus untuk siswa yang memiliki kemampuan metakognitif tinggi dimana hasil belajar fisika siswa yang menggunakan model IM lebih tinggi daripada yang menggunakan model IT.

4. Dari hasil perhitungan ANAVA yang telah dilakukan diatas, Hasil $\mathrm{F}_{\text {hitung }}$ dibandingkan dengan

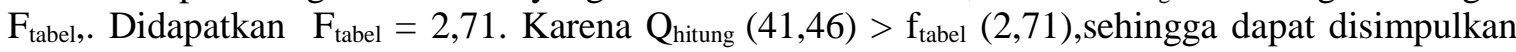
tidak terdapat perbedaan hasil belajar fisika yang signifikan antara yang menggunakan model IM dengan model IT khusus untuk siswa yang memiliki kemampuan metakognitif rendah dimana hasil belajar fisika siswa yang menggunakan model IM lebih rendah daripada yang menggunakan model IT. 


\section{SIMPULAN}

Berdasarkan hasil penelitian dan pembahasan, maka dapat disimpulkan bahwa: (1) Hasil belajar fisika yang menggunakan model IM lebih tinggi dibandingkan siswa yang menggunakan IT; (2) Tidak erdapat pengaruh interaksi antara model pembelajaran inkuiri dan kemampuan metakognitif;(3) Bagi siswa yang memiliki kemampuan metakognitif tinggi, hasil belajar fisika dengan model IM lebih tinggi daripada model IT; (4) Bagi siswa yang memiliki kemampuan metakognitif rendah, hasil belajar fisika dengan model IM lebih rendah daripada model IT.

\section{UCAPAN TERIMAKASIH}

Saya ucapkan banyak terimakasih kepada Prof. Dr. I Made Astra dan Dr. Betty Zelda,M. SMA Negeri 84 Jakarta dan SMA 96 Jakarta yang telah mendukung penelitian ini. Kedua orangtua, Mertua, Suami, anak dan teman-teman program magister pendidikan fisika UNJ 2013 yang terus meberikan do`a dan supportnya sehingga saya mampu menyelesaikan penulisan jurnal ini

\section{REFERENSI}

[1]. Abidin, Yunus. 2014. Desain Sistem Pembelajaran dalam Konteks Kurikulum 2013. Bandung: PT Refika Aditama

[2]. Anderson, L.W, Krathwohl, D.R. a taxonomy for learning, teaching and assesing; a revision of Bloom's taxonomy of educational objectives. A bridged edition. Addison wesley longman, Inc (2010), p. 94-139

[3]. Arikunto, Suharsimi. 1999. Dasar-dasar EvaluasiPendidikan. Jakarta: Bumi Aksara.

[4]. OECD, PISA 2012 result in focus: what 15-year-olds know and what they can do it what they know, Programme for international student assessment (2014), p. 5

[5]. Rahmatsyah, Simamora H. Pengaruh Ketrampilan Proses Sains Melalui Model Pembelajaran Inkuiri Terbimbing Terhadap Hasil Belajar Siswa Pada Materi Pokok Gerak di kelas VII SMP. Jurnal Penelitian Inovasi Pembelajaran Fisika

[6]. Sugiyono. 2009. Metode Penelitian Kuantitatif, Kualitatif dan R\&D. Bandung: Alfabeta 
